DOI:

\title{
İhtiyatlılık İlkesinin Finansal Sürdürülebilirlik Üzerindeki Etkisi: BIST Uygulaması *
}

Yusuf KURT**

\begin{abstract}
$\ddot{O Z Z T}$
Bu çalışma ile 2005-2019 yilları arasında Borsa İstanbul (BIST)'da kesintisiz olarak işlem gören işletmelere ait 15 yılllk veriler ylllk bazda incelenmiş ve bu verilerden hareketle işletmelerin ihtiyatlllkk düzeyleri ile finansal sürdürülebilirlikleri arasında bir iliş̧ki olup olmadiğ test edilmiștir. Finansal sürdürülebilirlik bağlaminda Türkiye Muhasebe ve Finansal Raporlama Standartları (TMS/TFRS) 'na göre raporlama yapan işletmelerin uzun vadede dönem kârı ve kapsaml kâr rakamları ile dönem sonu hisse senedi fiyatları ele alınmıştır. Isşletmelerin ihtiyatlllık düzeylerinin hesaplanmasında Givoly ve Hayn (2000) tarafindan geliştirilen "Negatif Tahakkuklar Yöntemi" kullanılmıştır. Araştırma ile işletmelerin finansal durum tabloları, nakit akıs tabloları ve kâr/zarar ve diğer kapsamlı gelir tablolarından faydalanılarak elden edilen veriler panel veri analizi yöntemi kullanılarak test edilmiştir. Araşstrma sonucunda işletmelerin ihtiyatlllık düzeyleri negatif olarak arttıkça, uzun dönemde işletmelerin toplam kapsamlı kârı ve dönem sonu hisse senedi fiyatlarının arttığı, dönem kârlarının ise azaldı̆̆ tespit edilmiştir.
\end{abstract}

Anahtar Kelimeler: Türkiye Muhasebe ve Finansal Raporlama Standartlarl, İhtiyatlllk Illkesi, Negatif Tahakkuklar Yöntemi, Finansal Sürdürülebilirlik, Kar Yönetimi.

JEL Sinıflandirmasi: M40, M41, M49.

\section{The Effect Of The Precautionary Principle On Financial Sustainability: BIST Application}

\section{ABSTRACT}

The businesses continuously traded in Borsa Istanbul (BIST) between 2005 and 2019 were analyzed on annual basis.It has been tested whether there is a relationship between the prudence levels of the businesses and their financial sustainability. In the context of financial sustainability, period profit and comprehensive profit figures and end-of-period stock prices of businesses reporting according to Turkish Accounting and Financial Reporting Standards (TAS/TFRS) were examined in the long run. Negative Accruals Method was used in calculating the prudence levels of businesses. In this research, the statement of financial position, cash flow statements and profit/loss and other comprehensive income statements of the companies were used. These collected data were tested by using the panel data statistical analysis method. Consequentially, as the prudence levels of the businesses increase negatively, the total comprehensive profit and the stock prices of the businesses at the end of the period increase and the period profits decrease in the long term.

Keywords: Turkish Accounting and Financial Reporting Standarts, Precautionary Principle, Negative Accrual Method, Financial Sustainability, Profit Management.

Jel Classification: M40, M41, M49

\footnotetext{
* Bu makale, "Muhasebe Standartlarında İhtiyatlılık İlkesi ve Finansal Sürdürülebilirlik İlişkisi: BIST Uygulamaları" adlı doktora tezinden türetilmiş olup, 23-25 Nisan 2021 tarihleri arasında gerçekleştirilen VI. Uluslararası Muhasebe ve Finans Sempozyumunda bildiri olarak sunulmuştur.

Makale Gönderim Tarihi: 07.05.2021, Makale Kabul Tarihi: 26.05.2021, Makale Türü: Nicel Analiz

** Öğr. Gör., Van Yüzüncü Yıl Üniversitesi, Özalp Meslek Yüksekokulu, yusufkurt@yyu.edu.tr, ORCID: 00000002-1071-4205
} 


\section{GİRiş}

“İhtiyatl1l1k” Genel Kabul Görmüş Muhasebe İlkeleri (GKGMI)’nin en önemlilerinden birisi iken, Uluslararası Muhasebe Standartları Kurulu (IASB) ve Amerikan Finansal Muhasebe Standartları Kurulu'nun (FASB), 2010-2017 yılları arasında Finansal Raporlamaya İlişkin Kavramsal Çerçeveleri'nde "ihtiyatlılık” kavramına yer vermemiş olmaları bir tartışma konusu olmuştur. IASB tarafından yayımlanan 2018 sürümlü Kavramsal Çerçeve'de ise ihtiyatlılık ilkesi yeniden düzenlenmiş ve ayrıntılı bir şekilde kavramsal çerçeveye dahil edilmiştir. $\mathrm{Bu}$ sebeple ihtiyatlılık kavramına ilişkin muhasebe literatüründe standart koyucular, araştırmacılar ve akademisyenler tarafından farklı eleştiriler yapılmış ve taraflar arasında bir fikir birliği sağlanamamıştır. İhtiyatlılık ilkesini savunan akademisyenler, işletmelerin iyimser davranarak varlık ve gelirlerini yüksek olarak muhasebeleştirmeleri ve yüksek hesaplanan karını ortaklara dağıtmalarının, uzun vadede işletmelerin sürdürülebilirliğini tehlikeye atacağını ve bunun da yatırımcıları zarara uğratacağını belirtmektedirler. Dolayısıyla işletmelerin gelecekteki olası risklerden korunmak amaciyla ihtiyatlılık ilkesine uygun raporlama yapılması gerektiğini vurgulamaktadırlar. İhtiyatlılık ilkesini eleştiren akademisyenler ise ihtiyatlılık ilkesinin zaman zaman kavramsal çerçevedeki değerleme ölçütleriyle çeliştiğini ve ihtiyatlılık ilkesinin gizli yedekler yaratması nedeniyle finansal tabloların tarafsızlığını zedelediğini ifade etmektedirler.

İşletmeler tarafından raporlanan kar rakamı genel olarak, işletme yöneticileri, çalışanlar ve diğer paydaşlar açısından önem arz etmektedir. Bu nedenle yüksek kar rakamı raporlayan işletmelerin piyasa değerleri artmakta ve işletme paydaşlarının refah düzeyi yükselmektedir. Ancak paydaşların refah düzeyinin uzun dönemler boyunca devam ettirebilmesi, işletmelerin finansal sürdürülebilirliklerine bağlıdır. Finansal sürdürülebilirlik ise, işletmelerin ihtiyatlılık ilkesine göre raporlama yapması ile sağlanmaktadır. Kısa vadede birbiri ile tezat olarak görünse de sürdürülebilirlik ile ihtiyatlılık arasındaki dengenin uzun vadede sağlanması gereği tartışmasız olarak literatürde kabul görmüştür.

$\mathrm{Bu}$ anlamda çalışmadaki amaç işletmelerin ihtiyatlılık düzeyleri ile finansal sürdürülebilirlikleri arasında anlamlı bir ilişki olup olmadığının tespit edilmesidir. Finansal sürdürülebilirlik açısından, TMS/TFRS'lere göre raporlama yapan işletmelerin dönem karı ve toplam kapsamlı kar rakamları ile, dönem sonu hisse senedi fiyatları ele alınmıştır. Çalışma kapsamında Borsa İstanbul'da işlem gören ve TMS/TFRS'leri uygulayan işletmelerin ihtiyatlılık düzeylerinin uzun vadede dönem karı, toplam kapsamlı kar ve dönem sonu hisse senedi fiyatı değişkenleri üzerindeki etkilerinin ortaya konulması amaçlanmıştır.

\section{LITERATÜR ÖZETI}

İhtiyatlılık ilkesi veya ihtiyatlılık ölçüm yöntemleri ile ilgili muhasebe literatüründe yapılan çalışmalara bakıldığında çalışmaların bir kısmının teorik ve kavramsal açıdan, bir kısmının ise ampirik açıdan ele alındığı görülmektedir.

\section{1. İhtiyatlılık İlkesini Kavramsal Açıdan İnceleyen Çalışmalar}

Watts (2003) tarafından yapılan çalışmada ihtiyatlılık ilkesinin önemi ve standart koyucular, paydaşlar, vergi ve yasalar açısından alternatif tanımlamalara değinilmiştir. Ayrıca 
ihtiyatlı uygulamaların yöneticilere ve diğer taraflara fazla ödeme yapılmasını engellediği ve ihtiyatlılığın standart koyucuların amaçları ile uyumlu olduğu ifade edilmiştir.

Jıng Lı (2013), ihtiyatlılık ilkesi ile borç sözleşmelerinin verimliliği arasındaki ilişkiyi test eden çalışmasında, yeniden müzakere edilebilir bir anlaşma üzerinden, borç sözleşmelerinin ihtiyatlılık ilkesi üzerindeki etkisini test etmek için bir teorik model geliştirmiştir. Buna göre anlaşma yeniden müzakere edilemediğinde ya da yeniden müzakere çok maliyetli olduğunda ihtiyatlılığın borç sözleşmelerinin verimliliğini azalttığı gözlemlenmiştir.

Gao (2013), ihtiyatlılık ilkesi üzerinde hakim olan tartışmalara farklı açılardan katkıda bulunan çalışmasında ise muhasebede uzun süren bir sezgi sonucu, muhasebe ölçümü üzerinde yöneticilerin meydana getirdiği fırsatçı etkilere karşı bir koruma görevi gören ihtiyatlılığa resmiyet kazandırmıştır. Ayrıca bu çalışma muhasebe kuralları üzerine odaklanmayı, muhasebe raporu üzerine odaklanmaya tercih ederek, ihtiyatlılığı bir ölçüm yöntemi olarak tasdik etmektedir.

Barker (2019), ihtiyatlılık ilkesinin kavramsal çerçevedeki yerini farklı açılardan ele alan çalışmasında ise ihtiyatlılık ilkesinin finansal raporlama konusunda makul bir özellik olup olmadığı konusunu değerlendirmiştir. Çalışmada; paydaşların kullanılabilirlik düzeyi açısından, ihtiyatlılık ilkesinin finansal raporlamada olması gerektiğine ilişsin sebeplerin olduğu ifade edilmiştir. Ayrıca ihtiyatlılık ilkesi tanımının uluslararası muhasebe standartları kurulu (IASB) tarafından revize edilmiş açıklamalarına değinilmiş ve ihtiyatlılık ilkesine muhasebenin kavramsal çerçevesi içerisinde yer verilmesi gerektiği savunulmuştur.

Ulusal yazında da ihtiyatlılık ilkesini kavramsal ve teorik açıdan inceleyen çalışmalar bulunmaktadır. Aktürk ve Acar (2012) tarafından yapılan çalışmada öncelikle ihtiyatlılık kavramın farklı tanımlarına, tarihsel gelişimine ve önemine değinilmiştir. Daha sonra ise yönetici kar payı sözleşmeleri, borç sözleşmeleri, maliyet artı kar sözleşmeleri ve iş sözleşmeleri bağlamında ihtiyatlılık kavramının temelleri üzerinde durulmuştur. Ayrıca İhtiyatlılık kavramının temelleri oluşturan kurumsal düzenlemeler Türkiye Muhasebe ve Finansal Raporlama Standartları (TMS/TFRS) açısından ele alınmıştır.

Ertuğrul (2014) ihtiyatlılık ilkesi bağlamında Uluslararası Muhasebe Standartları (UMS) ile geleneksel muhasebeyi karşılaştırmıştır. Bu çalışmada ayrıca varlık ve borçların gerçeğe uygun değerleriyle raporlanmasının ihtiyatlılık ilkesi ile çelişip çelişmediği incelenmiştir. Uluslararası Finansal Raporlama Standartları (UFRS) kavramsal çerçevede yer alan ihtiyatlılık kavramı ile değerleme ölçülerinin zaman zaman çeliştiği, tam açıklama ve hesap verme kavramlarıyla ters düştügü belirtilmiştir.

\section{2. İhtiyatlılık İlkesini Ampirik Açıdan İnceleyen Çalışmalar}

Ahmed ve Duellman (2007) tarafından 1999-2001 yıllarını kapsayan S\&P 500 endeksi dışında kalan 306 Amerikan firması üzerinde gerçekleştirilen çalışmada yönetim kurulunun yapısı ile ihtiyatlılık arasındaki ilişkiye odaklanılmıştır. Bu ilişkinin test edilmesinde negatif tahakkuklar yöntemi, kazançların asimetrik zamanlılığı ve piyasa değeri/defter değeri oranları kullanılmıştır. Çalışmanın sonucuna göre yönetim kurulundaki iç yöneticilerin oranı ile ihtiyatlılık arasında negatif bir ilişki, dış yöneticilerin işletme hisse senedi sahipliği ile 
ihtiyatlılık arasında ise pozitif bir ilişki tespit edilmiştir. Bu sonuçlar hisse senedi aracılık maliyetini azaltıcı etkisi bulunan ihtiyatlılık ilkesi ile uyumlu olduğu ifade edilmiştir.

Ahmed vd. (2002) tarafından, 1987-1998 yıllarını kapsayan 1323 Amerikan firması üzerinde ihtiyatlılık ölçüm yöntemlerinden negatif tahakkuklar yöntemi ve piyasa değeri/defter değeri oranları kullanılarak bir çalışma yapılmıştır. Hem piyasa bazlı, hem de tahakkuk bazlı ihtiyatlılık ölçümünün yapıldığı bu çalışmada kar dağıtım politikası üzerinde ihtiyatlılık ilkesinin daha fazla kullanılmasında işletmelerin çok ciddi çatışmalar yaşadığı ifade edilmiştir. İhtiyatlılık ilkesini daha fazla kullanan işletmelerin daha 1lımlı borçlanma oranlarına sahip olduğu belirtilmiştir. Sonuç olarak ihtiyatlılık ilkesinin düşük borçlanma maliyetleri ile bağlantılı olduğu tespit edilmiştir. Ayrıca kar dağıtım politikası ile tahvil ve hisse senedi sahipleri arasındaki çatışmaları hafifletmede ihtiyatlılık ilkesinin önemli bir rol oynadığı ifade edilmiştir.

Ahmed vd. (2000) tarafından en az 15 yıllık verilerle 1.074 firma üzerinde, "işletme varlıklarının değeri ve ihtiyatlılık" konusunda bir araştırma yapılmıştır. Bu araştırmada ihtiyatlılık ölçüm yöntemlerinden olan gizli yedekler yöntemi kullanılmıştır. Sonuç olarak muhasebe bazlı ihtiyatlılık ölçümü ile işletme varlıklarının değeri arasında pozitif bir ilişki olduğu tespit edilmiştir. Ayrıca bu ilişki gizli yedekler yönteminin de sahibi olan FelthamOhlson modeli ile desteklenmiştir.

Ball vd. (2008) tarafından 1992-2003 yılları arasında 22 ülkede 78.949 gözlem üzerinde, kazançların asimetrik zamanlılık yöntemi kullanılarak, finansal raporlamanın uygunluğu, zamanlılığı ve ihtiyatlılığı açısından borç piyasası ve hisse senedi piyasalarının ülkeler bazında farklılığı araştırılmıştır. Çalışmada; kazanç ve kayıpların tanınmasının zamanlılığının hisse senedi piyasalarının büyüklüğü ile bağlantılı olmadığı, aksine kayıpların zamanlı olarak tanınmasının borç piyasaları ile bağlantılı olduğu sonucuna ulaşılmıştır.

Ball vd. (2003) tarafından 1984-1996 yılları arasında Hong Kong, Malezya, Singapur ve Tayland olmak üzere dört Asya ülkesinden 2.726 veri toplanmıştır. Kazançların asimetrik zamanlılık yöntemi kullanılarak incelenen bu verilere göre ihtiyatlılık ilkesi üzerinde yasal, politik ve kurumsal faktörlerin etkisi incelenmiştir. Sonuç olarak bazı yasal, politik ve kurumsal faktörlerin ihtiyatlılık ilkesini etkilediği tespit edilmiştir. Ayrıca söz konusu ülkelerde finansal raporlamaların kalitesi kıyaslandığında, Hong Kong ve Singapur'da, Tayland ve Malezya'dan daha kaliteli finansal raporlama yapıldı̆̆ı ifade edilmiştir.

Bauman (1999), “Defter Değerinin Ölçümünde İhtiyatlılık İlkesinin Ampirik Araştırması" başlıklı çalışmasında 1980-1994 yılları arasında 6.171 Amerikan işletmesi verileri üzerinde Ohlson ve Feltham (1999) tarafından geliştirilen artık kar değerleme modelini (Residual İncome Valuation Model-RIVM) kullanmıştır. Bu çalışmanın sonucuna göre ihtiyatlılık derecesi ile reklam yoğunluğu, araştırma ve geliştirme yoğunluğu, ertelenmiş vergi borçları ve duran varlıkların yaşı arasında pozitif bir ilişkili olduğu gözlemlenmiştir. Ayrıca ihtiyatlılığın işletmelerin faaliyet kiralaması kullanımında bir azaltmaya neden olduğu tespit edilmiştir.

Beaty (2008), 1994-2004 yılları arasında, 3641 Amerikan firmasının borç sözleşmelerinin ihtiyatlılığını ortaya koyabilmek için ihtiyatlılık ölçüm yöntemlerinden kazançların asimetrik zamanlılığı, negatif tahakkuklar yöntemi ve piyasa değeri/ defter değeri 
yöntemlerini kullanmıştır. $\mathrm{Bu}$ çalışmanın sonucuna göre borç sözleşmelerindeki değişikliklerin ihtiyatlılık ilkesi ile bağlantılı olduğu tespit edilmiştir. Ayrıca bu çalışmanın hem akademisyenlerin hem de standart koyucuların ilgisini çekebileceği ifade edilmiştir.

Beaver ve Ryan (2003) tarafindan artık kar değerleme modeli (Residual İncome Valuation Model-RIVM) ile piyasa değeri/ defter değeri yöntemi kullanılarak, defter değerinin sürekli olarak piyasa değerinden yüksek/düşük oluşu (sürekli bileşim) ile beklenmedik kazanç/kayıpların hisse senedinin gelecekteki defter değeri (geçici bileşim) üzerindeki etkisi test edilmiştir. Sonuç olarak piyasa değeri/defter değeri oranının hisse senedinin gelecekteki defter değerini tahmin edebilmede başarısız olduğu, geliştirilen sürekli ve geçici bileşimlerle ispat edilmiştir. Ayrıca defter değerinin sürekli olarak piyasa değerinden yüksek veya düşük oluşunun işletmenin ihtiyatlılığı ile bağlantılı olduğu ifade edilmiştir.

Beekes vd. (2004) tarafindan, 1993-1995 yılları arasında Basu'nun ters regresyon yönteminin kullanıldığı 508 İngiltere firması üzerinde yapılan araştırmada kazançların zamanlılığı, koşullu ihtiyatlılık ve yönetim kurulu arasındaki ilişki test edilmiştir. Yönetim kurulunu oluşturan üyelerin büyük bir çoğunluğu işletme dışından ise bu firmaların kötü haberleri zamanında muhasebeleştirdiği gözlemlenmiştir. Yönetim kurulunu dışarıdan oluşturan üyeler çoğunluğu sağlamıyor ise bu firmaların iyi haberleri muhasebeleştirmede fazla ihtiyatlı olmadığı belirtilmiştir. Sonuç olarak İngiltere firmalarının kazançlarının kalitesinin belirlenmesinde yönetim kurulu üye oluşumunun önemli bir faktör olduğu vurgulanmıştır.

\section{ARAȘTIRMANIN VERILERİ VE YÖNTEM}

Bu bölümde işletmelerin ihtiyatlılık düzeylerinin, finansal sürdürülebilirliği ne ölçüde etkilediği test edilmektedir. $\mathrm{Bu}$ anlamda araştırmamızın amacı; TMS/TFRS'lere göre raporlama yapan işletmelerin ihtiyatlılık düzeyleri ile finansal sürdürülebilirlikleri arasındaki ilişsiyi incelemektir.

\subsection{Veri Ve Yöntem}

Araştırmamızda Borsa İstanbul'da 2005-2019 yılları arasında kesintisiz olarak işlem gören farklı sektörlerde faaliyet gösteren 16 işletmeye ait 15 y1llık veriler yıllık bazda incelenmiş ve toplam 960 veri üzerinde dinamik panel veri analizi yöntemi uygulanarak, işletmelerin ihtiyatlılık düzeyleri ile finansal sürdürülebilirlikleri arasında bir ilişki olup olmadığı test edilmiştir. Dinamik panel veri modellerinin el yordamıyla hesaplanması çok zor olduğundan, analizde EVIEWS 10 ve STATA 16.0 paket programları kullanılmıştır.

Finansal tablolara ilişkin verilerin bir kısmı Kamuyu Aydınlatma Platformu (KAP)'tan, diğer kısmı ise Borsa İstanbul'un veri deposu olan datastore'dan elde edilmiştir.

Araştırmada kullanılacak olan veri setimiz hem farklı işletmelere ilişkin kesit verilerini, hem de finansal tabloları incelenen işletmelerin dönem boyunca oluşmuş olan zaman serilerini içermektedir. Bu bakımdan araştırmamızın sonucuna sağlıklı bir şekilde ulaşabilmek için kullanılacak olan en uygun yöntem kesit ve zaman serilerinin birleştirilerek analiz edilmesine olanak sağlayan panel veri analizi yöntemidir. 
İşletmelerin ihtiyatlılık düzeylerinin tespit edilmesi konusunda literatürde beş farklı ölçüm yöntemi bulunmaktadır. Bu ölçüm yöntemleri; "Piyasa Değeri/Defter Değeri”, "Kazancın Asimetrik Zamanlılı̆̆ı", "Negatif Tahakkuklar", "Nakit Akışı- Asimetrik Tahakkuk" ve "Gizli Yedekler" yöntemleridir. Çalışmamızın araştırma bölümünde "Negatif Tahakkuklar Yöntemi" kullanılmıştır. Negatif tahakkuklar yönteminin tercih edilmesinin nedeni ise ihtiyatlılık düzeyinin hesaplanmasında diğer yöntemlerle karşılaştırıldığında bu yöntemde çok fazla veri setine ihtiyaç duyulmaması ve bu yöntemin borsaya kote olmayan işletmeler üzerinde de kolaylıkla uygulanabilmesinden kaynaklanmaktadır.

\subsection{Negatif Tahakkuklar Yöntemi}

"Negatif Tahakkuklar Yöntemi" Givoly ve Hayn (2000) tarafindan literatüre kazandırılmış olup faaliyetlerden sağlanan nakit akışları ile tahakkuklar arasındaki ilişkiye odaklanmaktadır. Givoly ve Hayn'ın nakit akışları ile tahakkuklar arasındaki ilişkiye odaklanmasının temel nedeni işletmenin ömrü boyunca elde edeceği amortisman öncesi karın işletme faaliyetlerinden sağlanan nakit akımına eşit olması gerekliliğini ortadan kaldıran unsurun "tahakkuklar" olmasından kaynaklanmaktadır.

İhtiyatlılık; muhasebenin tahakkuk mekanizmasını kullanarak ekonomik kazançların kaydedilmesini ertelemekte ve ekonomik kayıpların kaydedilmesini ise hızlandırmaktadır. Dolayısıyla kayıplar zamanında muhasebeleştirilmekte iken kazançlar kademeli olarak muhasebeleştirilmektedir. Bu sürecin sonucu olarak negatif tahakkuk farkı (net kar ve amortismanlar toplamının işletme faaliyetlerinden sağlanan nakit akımlarından az olması) ortaya çıkmakta ve bu tutar ne kadar büyük ise işletme o kadar ihtiyatlı olarak değerlendirilmektedir (Gülhan ve Karaarslan, 2019:99). Eğer uzun bir dönem boyunca işletmelerin finansal tablolarında negatif tahakkuklar gözlemlenirse, bu durum işletmenin ihtiyatlı olduğu şeklinde yorumlanmaktadır. formülleştirmiştir.

Givoly ve Hayn (2000) Negatif Tahakkuklar yöntemini aşağıdaki gibi

Negatif Tahakkuklar $=$ Toplam Tahakkuklar- Operasyonel Tahakkuklar

Toplam Tahakkuklar $($ Amortisman Öncesi $)=($ Net Kar + Amortismanlar $)-$ İşletme Faaliyetlerinden Nakit Akımı

İşletme Faaliyetlerine İlişkin (Operasyonel) Tahakkuklar $=\Delta$ Ticari Alacaklar $+\Delta$ Stoklar $+\Delta$ Peşin Ödenmiş Giderler- $\Delta$ Ticari Borçlar $-\Delta$ Ödenecek Vergiler

İhtiyatlılık ölçüm yöntemi olarak negatif tahakkuklar yöntemi kullanılmasının arkasında yatan mantık; ekonomik kazaçların yavaş (ötelenerek), ekonomik kayıpların hızlı bir şekilde kayda alınması sonucunda operasyonel olmayan tahakkuklar (negatif tahakkuklar) gittikçe negatif olarak artmaktadır. Negatif tahakkuklarda meydana gelen artış trendi ise ihtiyatlılık derecesindeki artışın bir göstergesidir. Toplam tahakkuklar; operasyonel tahakkuklar ile operasyonel olmayan tahakkuklar toplamından oluşmaktadır. Operasyonel tahakkuklar işletme faaliyetlerinin bir sonucu olarak ortaya çıkarken, operasyonel olmayan tahakkuklar ise borç ve gider karşılıkları, varlıklarda ortaya çıkan değer azalışları, borçların yeniden yapılandırılması, tahmin değişikliklerinin etkisi, varlık satışlarındaki kazanç-kayıplar 
ile giderlerin aktifleştirilmesi ve gelirlerin tanınma zamanının ertelenmesi gibi kalemler toplamını ifade etmektedir. (Givoly and Hayn, 2000:304). Dolayısıyla ihtiyatlılık ölçümünde negatif tahakkuk olarak ifade edilen yöntem operasyonel olmayan tahakkuklar toplamını ifade etmektedir.

Operasyonel olmayan tahakkuklar (negatif tahakkuklar)'ın hesaplanabilmesi için toplam tahakkuklardan operasyonel tahakkukların çıkartılması gerekmektedir. Operasyonel tahakkukların hesaplanabilmesi için işletmelerin finansal durum tablolarında raporlanan dönem içerisinde ortaya çıkan ticari alacaklar, stoklar ve peşin ödenmiş giderlerdeki değişimler toplamından, ticari borçlar ve ödenecek vergilerdeki değişim tutarlarının çıkartılması gerekmektedir. Toplam tahakkuklar ise işletmelerin dönem net karı ile amortismanlar toplamından, işletmelerin nakit akış tablosunun birinci bölümünden elde edilen işletme faaliyetlerinden nakit akışları toplamı çıkartılarak hesaplanmaktadır.

İhtiyatlılık ölçüsü olarak tahakkukların tutarının büyüklüğü ve yönü dikkate alınmaktadır. Zaman içinde birikimli olarak tahakkukların yönü değişebilmektedir. Başka bir ifade ile net karın işletme faaliyetlerden sağlanan nakit akımından fazla olduğu (pozitif tahakkuk) bir dönemden sonraki dönemlerde, net karın faaliyetlerden sağlanan nakit akımından az olması (negatif tahakkuk) beklenir. Tam tersi negatif tahakkukun olduğu dönemden sonra pozitif tahakkukun olduğu bir dönem gelmesi gerekir. Net karın nakit akımlarından az olduğu dönemler (negatif tahakkuk) uzun sürüyorsa, başka bir ifade ile tahakkuklarda beklenen yön değişimi gözlenemiyorsa ihtiyatlllıktan bahsedilmektedir. Ayrıca, tahakkukların zaman içindeki birikim oranı da ihtiyatlılı̆̆ın değişim derecesini göstermektedir (Vardar, 2018:66). Başka bir ifadeyle işletmelerin dönem boyunca amortisman ve değer düşüklükleri öncesindeki net karı işletme faaliyetlerinden sağlanan nakit akışları toplamına eşittir. Fakat işletmelerde tahakkuk ilkesinin uygulanmasının sonucu olarak dönemler arasında dengesiz dağılımlar görülebilir. Net kar işletme faaliyetlerinden sağlanan nakit akışlarının altına düşerse, ilerleyen dönemlerde pozitif tahakkukların olması yani net karın işletme faaliyetlerinden sağlanan nakit akışlarını geçmesi beklenmektedir. Uzun bir dönem boyunca işletmelerin finansal tablolarında negatif tahakkukların gözlemlenmesi, işletmelerin ihtiyatlı olduğunu göstermektedir. (Givoly and Hayn, 2000:307).

\subsection{Hipotezler}

Araştırmanın hipotezleri aşağıdaki gibidir.

$\mathrm{H}_{1}$ : TMS/TFRS'leri uygulayan işletmelerin ihtiyatlılık düzeylerinin artması, uzun vadede dönem karında dengeli bir artış sağlamaktadır.

$\mathrm{H}_{2}$ : TMS/TFRS'leri uygulayan işletmelerin ihtiyatlılık düzeylerinin artması, uzun vadede kapsamlı karda dengeli bir artış sağlamaktadır.

$\mathrm{H}_{3}$ : TMS/TFRS'leri uygulayan işletmelerin ihtiyatlılık düzeylerinin artması, dönem sonu hisse senedi fiyatlarını da artırmaktadır. 


\subsection{Analiz ve Bulgular}

İşletmelerin ihtiyatlllık düzeyleri ile finansal sürdürülebilirlikleri arasındaki ilişki dört değişken üzerinden test edilmiştir. Bu değişkenler ihtiyatlılık düzeyi, dönem karı, toplam kapsamlı kar ve dönem sonu hisse senedi fiyatlarıdır. Araştırmada kullandığımız değişkenlerden ihtiyatlılık düzeyi bağımlı değişken, dönem karı, toplam kapsamlı kar ve dönem sonu hisse senedi fiyatları ise bağımsız değişkenler olarak dikkate alınmıştır.

Araştırmada ihtiyatlılık düzeyi ile finansal sürdürülebilirlik arasındaki ilişkinin test edilmesinde kullanılacak olan fonksiyon aşağıdaki gibidir.

$\mathrm{IHT}=\mathrm{f}(\mathrm{K} / \mathrm{Z}, \mathrm{KK} / \mathrm{Z}, \mathrm{HF})$

Modeldeki değişkenlerin açılımı ise aşağıdaki gibidir.

IHT= İhtiyatl1lık Düzeyi

K/Z = Dönem Kar/Zararı

$\mathrm{KK} / \mathrm{Z}=$ Toplam Kapsamlı Kar/Zarar

HF= Dönem Sonu Hisse Senedi Fiyatı

Araştırmamızda genel olarak işletmelerin ihtiyatlılık düzeyi ile finansal sürdürülebilirlik arasındaki kurulan ekonometrik model ise aşağıda verilmiştir.

$$
\mathrm{IHT}_{\mathrm{i}, \mathrm{t}}=\beta_{0}+\beta_{1} \mathrm{~K} / \mathrm{Z}_{\mathrm{i}, \mathrm{t}}+\beta_{2} \mathrm{KK} / \mathrm{Z}_{\mathrm{i}, \mathrm{t}}+\beta_{3} \mathrm{HF}_{\mathrm{i}, \mathrm{t}}+\varepsilon_{\mathrm{i}, \mathrm{t}}
$$

Tablo 1'de bağımlı ve bağımsız değişkenlere ait korelasyon değerleri yer almaktadır. Değişkenlere ait korelasyon tablosunun incelenmesinin temel olarak iki önemi vardır. Öncelikle bağımsız değişkenler arası yüksek korelasyon olduğu durumlarda çoklu bağlantı problemleri ${ }^{1}$ ortaya çıkmaktadır. Bu durumlarda analiz sonucu önemli ölçüde etkilenmektedir. İkinci olarak korelasyon tablosundaki bağımlı ve bağımsız değişkenler arasındaki tek yönlü ilişkinin bir göstergesidir. Çoklu değişken analizi yapılmadan önce tek yönlü değişkenler arasındaki korelasyonun incelenmesi bağımlı ve bağımsız değişkenler arasındaki ilişkinin kuvveti ve yönü hakkında araştırmacıya ön bilgi sağlamaktadır (Yıldırım ve Kostakoğlu, 2015:105).

Tablo 1: Korelasyon Analizi Sonuçları

\begin{tabular}{|c|c|c|c|c|}
\hline DEĞişKENLER & IHT & K/Z & KK/Z & HF \\
\hline IHT & 1.000 & & & \\
\hline K/Z & 0,0876 & 1.000 & & \\
\hline KK/Z & $-0,0520$ & 0,8811 & 1.000 & \\
\hline HF & $-0,0506$ & 0,0885 & 0,0956 & 1.000 \\
\hline
\end{tabular}

\footnotetext{
${ }^{1}$ Çoklu bağlantı problemi, açıklayıcı değişkenlerin kendi içerisinde tam veya tama yakın doğrusal ilişkiye sahip olması durumudur.
} 
Bağımlı değişken ile bağımsız değişkenler arasında korelasyon analizi sonuçlarına ilişkin Tablo 11 incelendiğinde işletmelerin ihtiyatlılık düzeyleri ile dönem kar/zararı arasındaki korelasyon katsayısının 0,0876 olduğu gözlemlenmektedir. $\mathrm{Bu}$ katsayı yorumlandığında; bağımlı değişken olan ihtiyatlılık düzeyi ile bağımsız değişken olan dönem kar/zararı arasında pozitif ve aşırı zayıf bir ilişki olduğunu göstermektedir.

Bağımlı değişken olan ihtiyatlılık düzeyi ile bağımsız değişken olan toplam kar/zarar değişkeni arasındaki korelasyon katsayısının -0,0520 olduğu gözlemlenmektedir. Bu katsayı yorumlandığında; ihtiyatlılık düzeyi ile toplam kar/zarar değişkeni arasında negatif ve aşırı zayıf bir ilişki olduğu görülmektedir

Bağımlı değişken olan ihtiyatlılık düzeyi ile bağımsız değişken olan dönem sonu hisse senedi fiyatı arasında korelasyon katsayısının -0,0506 olduğu gözlemlenmektedir. Bu katsayı yorumlandığında; ihtiyatlılık düzeyi ile dönem sonu hisse senedi fiyatı arasında negatif ve aşırı zayıf bir ilişki olduğu görülmektedir.

Araştırmada bağımsız değişkenlerimiz olan dönem kar/zararı, toplam kapsamlı kar/zarar ve dönem sonu hisse senedi fiyatı değişkenlerinin kendi aralarında yüksek korelasyona sahip olmaması başka bir ifade ile aralarında çoklu bağlantı problemi olmaması gerekmektedir. Korelasyon analiz sonuçları tablosunda korelasyon katsayılarının 0,90'dan büyük olmaması çoklu bağlantı problemi olmadığının göstergesidir. Çoklu bağlantı problemi olmadığının bir diğer göstergesi de Varyans Şişirme Faktör (Variance Inflation Factor-VIF) değerleridir. VIF değerlerinin ise 10'dan küçük olması çoklu bağlantı probleminin olmadığını göstermektedir (Topaloğlu, 2018:21)

Korelasyon analizi sonuçları çoklu bağlantı problemi açısından değerlendirildiğinde bağımsız değişkenler arasında en yüksek korelasyon katsayısının 0,8811 olduğu görülmektedir. Bu katsayı değeri 0,90'dan küçük olduğundan çoklu bağlantı problemi bulunmamaktadır. Tablo 2'de bağımsız değişkenler için VIF sonuçlarına bakıldığında tabloda yer alan değerlerin 10'dan küçük olması, çoklu bağlantı problemi olmadığını destekler niteliktedir.

Tablo 2. Varyans Şişirme Faktör Değerleri

\begin{tabular}{|c|c|c|}
\hline DEĞIŞKENLER & VIF & 1/VIF \\
\hline K/Z & 4,48 & 0,223333 \\
\hline KK/Z & 4,47 & 0.223628 \\
\hline HF & 1,01 & 0.990780 \\
\hline ORTALAMA & 3,32 & 0,479247 \\
\hline
\end{tabular}

\subsection{Yatay Kesit Bağımlılığının Test Edilmesi}

Yatay kesit bağımsızlığı, paneli oluşturan birimlerin herhangi birisine gelen makroekonomik bir şoktan paneli oluşturan diğer birimlerin etkilenmediği varsayımına dayanmaktadır. $\mathrm{Bu}$ başlık altında, analize dahil edilen işletmeler arasında yatay kesit bağımlılığı olup olmadığı test edilecektir. Çünkü bir sonraki aşamada yapılacak olan birim kök testlerinin varlığının araştırılmasında birinci nesil birim kök testleri mi, yoksa ikinci nesil birim kök testlerinin tercih edilmesi konusunda, seriler arasında yatay kesit bağımlılığı olup olmadığı önem taşımaktadır. 
Seriler arasında yatay kesit bağımlılı̆̆ının varlığı; Berusch-Pagan (1980) LM testiyle ya da Pesaran (2004) CD testiyle incelenebilmektedir. Berusch-Pagan (1980) LM testi zaman boyutu yatay kesit boyutundan büyük olduğu durumlarda, yani $(T>N)$, Pesaran (2004) CD testi ise hem zaman boyutu yatay kesit boyutundan büyük, hem de yatay kesit boyutu zaman boyutundan büyük olduğu durumlarda $(\mathrm{T}>\mathrm{N}, \mathrm{N}>\mathrm{T})$ kullanılabilmektedir.

Yatay kesit bağımlı̆̆ı sonucunda aşağıdaki hipotezler test edilmektedir.

$\mathrm{H}_{0}$ : Yatay kesit bağımlılı̆̆ yoktur.

$\mathrm{H}_{1}$ : Yatay kesit bağımlılığı vardır.

Test sonucunda elde edilecek olasıl1k değeri 0.05 'ten küçük olduğunda $(\mathrm{p}<0,05), \mathrm{H}_{0}$ hipotezi $\% 5$ anlamlılık düzeyinde reddedilmekte ve bu durum paneli oluşturan birimler arasında yatay kesit bağımlılı̆̆ı olduğuna işaret etmektedir (Göçer vd,2012:456). Seriler arasında yatay kesit bağımlığının test edilmesinde, zaman boyutu yatay kesit boyutundan büyük olduğu için $(\mathrm{T}>\mathrm{N})$ Berusch-Pagan (1980) LM testi tercih edilmiştir.

Yatay kesit bağımlılık test sonucu aşağıdaki tabloda verilmiştir.

Tablo 3. Panel Bazında Yatay Kesit Bağımlılık Test Sonuçları

\begin{tabular}{|l|l|l|}
\hline \multicolumn{1}{|c|}{ Test Değerler } & İstatistik Değeri & Olasılık Değeri (P) \\
\hline Breusch-Pagan LM Testi & 1.113202 & 0.2914 \\
\hline
\end{tabular}

$\mathrm{H}_{0}$ : Yatay kesit bağımlılı̆̆ yoktur.

$\mathrm{H}_{1}$ : Yatay kesit bağımlılı̆̆ı vardır.

Tablo 3’te Breusch-Pagan LM Testi sonuçlarına bakıldığında p>0,05 olduğundan, \%5 anlamlılık düzeyinde $\mathrm{H}_{0}$ hipotezi kabul edilmiştir. Bunun anlamı paneli oluşturan yatay kesit birimlerinin, seriye gelen bir şok karşısında birbirlerinden etkilenmediklerini ifade etmektedir. Dolayısıyla $\mathrm{H}_{0}$ hipotezi kabul edilerek, seriler arasında "yatay kesit bağımlılı̆̆ sonucuna ulaşılmıştır.

Bu nedenle bir sonraki aşamada yapılacak olan panel birim kök testleri analizinde seriler arasında yatay kesit bağımlılığını dikkate almayan panel birim kök testleri tercih edilmiştir.

\subsection{Panel Birim Kök Testi (Panel Durağanlık)}

Panel veri analizi yönteminde tutarlı sonuçlara ulaşabilmek için yatay kesit bağımlılığı test edildikten sonra panel birim kök testleri ile zaman serilerinin durağan olup olmadığının test edilmesi gerekmektedir. Başka bir ifade ile bağımlı ve bağımsız değişkenler arasında anlamlı sonuçların sağlanabilmesi için serilerin durağan olması gerekmektedir. $\mathrm{Bu}$ anlamda panel birim kök testleri (panel durağanlık), yatay kesit bağımlılığı testinde elde edilen sonuçlara göre birinci ve ikinci nesil birim kök testleri olmak üzere ikiye ayrılmaktadır 
(Topaloğlu, 2018:24) Panel veri setinde yatay kesit bağımlılığının varlığı kabul edilirse 2. nesil birim kök testleri, yatay kesit bağımlılığının varlığı reddedilirse 1 . nesil birim kök testlerini kullanmak daha tutarlı, güçlü ve etkin tahminler yapılmasını sağlamaktadır (Çınar, 2010:495). Araştırmamızda seriler arasında yatay kesit bağımlılığı bulunmadığından, başka bir deyişle analize dahil edilen işletmelerin birisine gelen bir şok, diğer işletmeleri etkilemeyeceğinden panel birim kök testinde 1. nesil birim kök testleri uygulanmıştır.

Araştırmamızda uygulanabilecek birinci nesil birim kök testleri de paneli oluşturan yatay kesitlerin homojen ya da heterojen olmaları durumuna göre ikiye ayrılmaktadır. Levin, Lin ve Chu-LLC (2002), Breitung (2005) ve Hadri (2000) homojenlik varsayımına dayanırken; Im, Pesaran ve Shin-IPS (2003), Maddala ve Wu (1999), Choi (2001) heterojenlik varsayımına dayanmaktadır (Göçer, 2012:457). Homojenlik varsayımına dayanan testler, paneli oluşturan birimlerin benzer niteliklere sahip oldukları durumlarda, heterojenlik varsayımına dayanan testler ise paneli oluşturan birimlerin farklı niteliklere sahip oldukları durumlarda tercih edilmektedir. Bu testler içerisinde Hadri (2000) testinde sıfir hipotezi paneli oluşturan verilerin birim kök içermedikleri yönünde iken, diğer testlerde sıfır hipotezi paneli oluşturan verilerin birim kök içerdikleri şeklindedir (İltaş, 2017:570) Başka bir ifade ile Hadri (2000) testi hariç diğer testlerin sonucunda birim kök bulunması panel verinin durağan olmadığ

$\mathrm{H}_{0}$ : Seriler durağan değildir. (Birim kök vardır)

$\mathrm{H}_{1:}$ Seriler durağandır. (Birim kök yoktur.)

Bağımlı ve bağımsız değişkenlere ait 1. nesil birim kök testi sonuçları aşağıdaki tabloda gösterilmiştir.

Tablo 4. Panel Birim Kök Testi Sonuçları

\begin{tabular}{|c|c|c|c|c|c|c|}
\hline & \multicolumn{3}{|c|}{ Levin-Lin-Chu (LLC) Testi } & \multicolumn{3}{|c|}{ Im-Pesaran-Shin (IPS)Testi } \\
\hline \multirow{4}{*}{ IHT } & & T-İstatistik & P Değeri & & T- İstatistik & P Değeri \\
\hline & Sabitli & -1.5066 & 0.0660 & Sabitli & -0.74919 & 0.2269 \\
\hline & $\begin{array}{l}\text { Sabitli- } \\
\text { Trendli }\end{array}$ & -5.04037 & 0.0000 & $\begin{array}{l}\text { Sabitli- } \\
\text { Trendli }\end{array}$ & -2.31803 & 0.0102 \\
\hline & None & -4.90727 & 0.0000 & None & & \\
\hline & \multicolumn{3}{|c|}{ Levin-Lin-Chu (LLC) Testi } & \multicolumn{3}{|c|}{ Im-Pesaran-Shin (IPS)Testi } \\
\hline \multirow{4}{*}{$K / Z$} & & T-İstatistik & P Değeri & & T- İstatistik & P Değeri \\
\hline & Sabitli & 2.83240 & 0.9977 & Sabitli & 5.16098 & 1.0000 \\
\hline & $\begin{array}{l}\text { Sabitli- } \\
\text { Trendli }\end{array}$ & -3.07360 & 0.0011 & $\begin{array}{l}\text { Sabitli- } \\
\text { Trendli }\end{array}$ & -0.04253 & 0.4830 \\
\hline & None & 5.12525 & 1.0000 & None & & \\
\hline
\end{tabular}




\begin{tabular}{|c|c|c|c|c|c|c|}
\hline & \multicolumn{3}{|c|}{ Levin-Lin-Chu (LLC) Testi } & \multicolumn{3}{|c|}{ Im-Pesaran-Shin (IPS)Testi } \\
\hline \multirow{4}{*}{$\mathbf{K K} / \mathbf{Z}$} & & T-İstatistik & P Değeri & & T- İstatistik & P Değeri \\
\hline & Sabitli & 8.90374 & 1.0000 & Sabitli & 10.0860 & 1.0000 \\
\hline & $\begin{array}{l}\text { Sabitli- } \\
\text { Trendli }\end{array}$ & 1.14493 & 0.8739 & $\begin{array}{l}\text { Sabitli- } \\
\text { Trendli }\end{array}$ & 3.92031 & 1.0000 \\
\hline & None & 6.74070 & 1.0000 & None & & \\
\hline & \multicolumn{3}{|c|}{ Levin-Lin-Chu (LLC) Testi } & \multicolumn{3}{|c|}{ Im-Pesaran-Shin (IPS)Testi } \\
\hline \multirow{4}{*}{ HF } & & T-İstatistik & P Değeri & & T- İstatistik & P Değeri \\
\hline & Sabitli & -2.33264 & 0.0098 & Sabitli & 0.21761 & 0.5861 \\
\hline & $\begin{array}{l}\text { Sabitli- } \\
\text { Trendli }\end{array}$ & -7.98894 & 0.0000 & $\begin{array}{l}\text { Sabitli- } \\
\text { Trendli }\end{array}$ & -2.88058 & 0.0020 \\
\hline & None & 2.14768 & 0.9841 & None & & \\
\hline
\end{tabular}

Analize dahil edilen veriler LLC ve IPS testleri ile sabit, sabit-trendli ve none modelleri çerçevesinde $\% 5$ anlamlılık seviyesinde test edilmiştir. LLC testi sonucunda ihtiyatlılık düzeyi değişkeni için sabitli-trendli ve none modellerinde, dönem kar zarar değişkeni için sabitli-trendli model ve dönem sonu hisse senedi fiyatı değişkeni için sabitlitrendli modellerde $\mathrm{p}<0,05$ olduğundan $\mathrm{H}_{0}$ hipotezi reddedilmiştir ve serilerin durağan olduğu tespit edilmiştir. IPS testi sonucunda ise ihtiyatlılık düzeyi değişkeni için sabitli-trendli modelde, dönem sonu hisse senedi fiyatı değişkeni için sabitli-trendli modellerde $\mathrm{p}<0,05$ olduğundan $\mathrm{H}_{0}$ hipotezi reddedilmiştir ve serilerin durağan olduğu tespit edilmiştir. Fakat ihtiyatlılık düzeyi değişkeni için hem LLC hem de IPS testlerinde sabitli modelde, dönem kar/zarar değişkeni için LLC testinde sabitli ve none modellerde, dönem kar/zarar değişkeni için IPS testinde sabitli ve sabitli-trendli modellerde, toplam kapsamlı kar/zarar değişkeni için LLC testinde sabitli, sabitli-trendli ve none modellerinde, toplam kapsamlı kar/zarar değişskeni için IPS testinde sabitli ve sabitli-trendli modellerde, dönem sonu hisse senedi fiyatı değişkeni için LLC testinde none modelinde ve dönem sonu hisse senedi fiyatı değişkeni için IPS testinde sabitli modelde birim kök vardır ve seriler durağan değildir.

Panel veri analizinde sağlıklı ve doğru bilgilere ulaşabilmek için, panel veri serilerinin durağan olması gerekmektedir. Panel veri analizine devam edebilmek için durağan olmayan seriler için değişkenlerin ilk farkları alınarak serilerin durağan hale getirilmesi gerekmektedir. $\mathrm{Bu}$ nedenle aynı anlamlılık düzeyinde bağımlı ve bağımsız değişkenler ilk farkları alınarak tekrar test edilmiştir. Test sonuçları ise aşağıdaki tabloda gösterilmiştir. 
Tablo 5. Panel Birim Kök Testi Birinci Fark Sonuçları

\begin{tabular}{|c|c|c|c|c|c|c|}
\hline & Levin-Li & Chu (LLC) & & Im-Pesa & 1-Shin (IPS) & \\
\hline & & T-İstatistik & P Değeri & & T- İstatistik & P Değeri \\
\hline & Sabitli & -10.9912 & 0.0000 & Sabitli & -10.9821 & 0.0000 \\
\hline IHT & $\begin{array}{l}\text { Sabitli- } \\
\text { Trendli }\end{array}$ & -15.1060 & 0.0000 & $\begin{array}{l}\text { Sabitli- } \\
\text { Trendli }\end{array}$ & -11.8425 & 0.0000 \\
\hline & None & -15.4134 & 0.0000 & None & & \\
\hline & Levi & Lin-Chu (LI & Testi & Im- & aran-Shin ( & ) Testi \\
\hline & & T-İstatistik & P Değeri & & T- İstatistik & P Değeri \\
\hline & Sabitli & -9.38281 & 0.0000 & Sabitli & -7.29962 & 0.0000 \\
\hline $\mathbf{K} / \mathbf{Z}$ & $\begin{array}{l}\text { Sabitli- } \\
\text { Trendli }\end{array}$ & -12.5863 & 0.0000 & $\begin{array}{l}\text { Sabitli- } \\
\text { Trendli }\end{array}$ & -8.24455 & 0.0000 \\
\hline & None & -8.77253 & 0.0000 & None & & \\
\hline & Levi & Lin-Chu (L1 & Testi & Im- & saran-Shin ( & ) Testi \\
\hline & & T-İstatistik & P Değeri & & T- İstatistik & P Değeri \\
\hline & Sabitli & -9.78679 & 0.0000 & Sabitli & -7.69423 & 0.0000 \\
\hline KK/Z & $\begin{array}{l}\text { Sabitli- } \\
\text { Trendli }\end{array}$ & -14.9887 & 0.0000 & $\begin{array}{l}\text { Sabitli- } \\
\text { Trendli }\end{array}$ & -13.3691 & 0.0000 \\
\hline & None & -11.0528 & 0.0000 & None & & \\
\hline & Levi & Lin-Chu (Ll & ) Testi & Im- & saran-Shin ( & ) Testi \\
\hline & & T-İstatistik & P Değeri & & T- İstatistik & P Değeri \\
\hline & Sabitli & -19.2271 & 0.0000 & Sabitli & -13.7391 & 0.0000 \\
\hline HF & $\begin{array}{l}\text { Sabitli- } \\
\text { Trendli }\end{array}$ & $\begin{array}{l}-18.4708 \\
\end{array}$ & 0.0000 & $\begin{array}{l}\text { Sabitli- } \\
\text { Trendli }\end{array}$ & -12.3311 & 0.0000 \\
\hline & None & -16.9589 & 0.0000 & None & & \\
\hline
\end{tabular}


Bağımlı ve bağımsız değişkenler için yapılan panel birim kök testi birinci fark sonuçlarına ilişkin Tablo 5'e bakıldığında LLC ve IPS testlerine ait sabitli, sabitli-trendli ve none modellerinin tümünde $\mathrm{p}<0,05$ olduğu gözlemlenmiştir. Başka bir ifadeyle ihtiyatlılık düzeyi, dönem kar/zararı, kapsamlı kar/zarar ve dönem sonu hisse senedi fiyat1 değişkenlerinin birinci farkları alınmak suretiyle yapılan birim kök testinde, tüm değişkenlerin birim kök içermediği, yani durağan olduğu sonucuna ulaşılmıştır.

Dinamik panel veri analizinde birinci farkta durağan olan değişkenler, farkları alınmış halleriyle kullanılmışlardır.

Tablo 6. Dinamik Panel Veri Analizi Sonuçları

\begin{tabular}{|c|c|c|c|c|}
\hline \multirow[b]{2}{*}{ Değişkenler } & \multicolumn{2}{|c|}{ Fark GMM } & \multicolumn{2}{|c|}{ Sistem GMM } \\
\hline & $\begin{array}{c}\text { Tek Aşamalı } \\
\text { GMM }\end{array}$ & $\begin{array}{c}\text { İki Aşamalı } \\
\text { GMM }\end{array}$ & $\begin{array}{l}\text { Tek Aşamalı } \\
\text { Sistem GMM }\end{array}$ & $\begin{array}{l}\text { İki Aşamalı } \\
\text { Sistem GMM }\end{array}$ \\
\hline $\mathrm{IHT}_{\mathrm{t}-1}$ & $\begin{array}{c}-7.849516 \\
(0.0000)\end{array}$ & $\begin{array}{l}-0.555643 \\
(0.0000)^{*}\end{array}$ & $\begin{array}{c}-0.7362671 \\
(0.000)\end{array}$ & $\begin{array}{c}-0.7421592 \\
(0.0000)^{*}\end{array}$ \\
\hline $\mathrm{K} / \mathrm{Z}$ & $\begin{array}{l}3.333771 \\
(0.0010)\end{array}$ & $\begin{array}{l}1.105023 \\
(0.0000)^{*}\end{array}$ & $1.059003(0.0000)$ & $\begin{array}{l}1.177275 \\
(0.0000)^{*}\end{array}$ \\
\hline $\mathrm{KK} / \mathrm{Z}$ & $\begin{array}{c}-2.483659 \\
(0.0138)\end{array}$ & $\begin{array}{l}-0.423619 \\
(0.0000)^{*}\end{array}$ & $\begin{array}{c}-0.4607597 \\
(0.006)\end{array}$ & $\begin{array}{c}-0.3361028 \\
(0.0000)^{*}\end{array}$ \\
\hline $\mathrm{HF}$ & $\begin{array}{c}-38674.90 \\
(0.3254)\end{array}$ & $\begin{array}{l}-53853.76 \\
(0.0067)^{*}\end{array}$ & -8298.871 (0.689) & $\begin{array}{c}-47183.32 \\
(0.0460) * *\end{array}$ \\
\hline Wald Testi & $\begin{array}{l}4.170448 \\
(0.0068)\end{array}$ & $\begin{array}{l}2491.743 \\
(0.0000)^{*}\end{array}$ & $128.74(0.0000)$ & $2.08 \quad(0.0000)^{*}$ \\
\hline $\begin{array}{c}\text { Sargan-Hansen } \\
\text { Testi }\end{array}$ & $\begin{array}{l}198.2948 \\
(0.0000)\end{array}$ & $\begin{array}{c}11.6837 \\
(0.471401)\end{array}$ & $212.92(0.0000)$ & $13.46 \quad(0.997)$ \\
\hline AR1 & $\begin{array}{c}-7.796034 \\
(0.0000)\end{array}$ & $\begin{array}{c}-1.392299 \\
(0.1638)\end{array}$ & $-2.65 \quad(0.008)$ & $-1.45 \quad(0,147)$ \\
\hline AR2 & $\begin{array}{c}2.663599 \\
(0.0077)\end{array}$ & $\begin{array}{l}0.879015 \\
(0.3794)\end{array}$ & $0.15 \quad(0.881)$ & $\begin{array}{c}0.20 \\
(0.844)\end{array}$ \\
\hline
\end{tabular}

Not: Parantez içerisinde verilen değerler olasılık değerlerini, parantez üzerindeki değerler ise modele ilişkin katsayıları göstermektedir. Ayrıca * ve ${ }^{* *}$ sırasıyla $\% 1$ ve $\% 5$ istatistiki anlamlılık düzeyini göstermektedir.

Tablo 6' da bağımlı ve bağımsız değişkenler arasındaki ilişki, Fark GMM ve Sistem GMM tahmincileri altında tek aşamalı ve iki aşamalı şekilde test edilmiştir. Her bir tahmincinin varsayım testleri ise tablonun sonunda verilmiştir. Dinamik panel veri analizine ilişkin sonuçların değerlendirilmesinde öncelikle GMM Tahmincileri için varsayım testlerinin sonuçlarına bakılması gerekmektedir. Varsayım testleri GMM tahmincilerinin geçerliliğinin sağlanması amacıyla yapılmaktadır. Buna göre; modelde bulunan katsayıların bireysel anlamlılıklarını test etmek ve kurulan modelin anlamlı olup olmadığını belirlemek amacıyla başvurulan Wald Testi olasılık değerinin her bir tahminci için $\mathrm{p}<0,05$ olduğu görülmektedir. 
Modelde kullanılan bağımsız değişkenlerin bağımlı değişkeni açıklama gücünün sınanmasında Wald testine ait hipotezler ise aşağıdaki gibidir.

$\mathrm{H}_{0}$ : Bağımsız değişkenler bağımlı değişkeni açıklamada yeterli değildir.

$\mathrm{H}_{1}$ : Bağımsız değişkenler bağımlı değişkeni açıklamada yeterlidir.

Wald testi olasılık değerinin $\mathrm{p}<0,05$ olması kurulan modelin anlamlı olduğunu göstermektedir. Bu durumda sıfır hipotezi reddedilmiştir ve alternatif hipotez kabul edilmiştir.

GMM tahmininde kullanılan araç değişkenlerin dışsal olması, başka bir ifade ile değişkenler arasında içsellik problemi olmaması gerekmektedir. Sargan-Hansen Testinde sıfır hipotezinin kabul edilmesi beklenmektedir. Sargan-Hansen Testi hipotezleri ise aşağıdaki gibidir.

$\mathrm{H}_{0}$ : Araç değişkenler dışsaldır. (Moment koşulları geçerlidir)

$\mathrm{H}_{1}$ : Araç değişkenler içseldir. (Moment koşulları geçerli değildir)

Tablo 6'da Sargan-Hansen testi sonuçlarına bakıldığında ise Fark GMM ve Sistem GMM tahmincileri tek aşamalı modellerin olasılık değerinin $p<0,05$ olduğu görülmektedir. $\mathrm{Bu}$ değer modellerde kullanılan araç değişkenlerin içsel olduğunu ifade etmektedir. $\mathrm{Bu}$ durumda Sargan-Hansen testine ait sifır hipotezi reddedilerek Fark GMM ve Sistem GMM tahmincileri tek aşamalı modellerinin bir bütün olarak anlamsız olduğu sonucuna ulaşılmıştır. Dolayısıyla araştırmamızda kurulan hipotezlerin test edilmesinde söz konusu modeller kapsam dışında bırakılmıştır. Fakat tabloda Fark GMM ve Sistem GMM tahmincileri iki aşamalı modellerin olasılık değerinin $\mathrm{p}>0,05$ olduğu görülmektedir. Bu sonuç Fark GMM ve Sistem GMM tahmincileri iki aşamalı modellerinin anlamlı olduğunu yani modelde kullanılan araç değişkenlerin içsel olmadığını göstermektedir.

Değişkenler arasında bir otokorelasyon problemi olup olmadığını belirlemek amacıyla yapilan Arellano ve Bond'un otokorelasyon testinde (AR1-AR2 testi) GMM tahmincisinin etkin olabilmesi için ikinci mertebeden otokorelasyon problemi olmaması gerekmektedir. $\mathrm{Bu}$ testte temel hipotez "otokorelasyon yoktur" şeklinde kurulmaktadır. Modelde ikinci mertebeden otokorelasyon olmaması GMM tahminlerinin tutarlılığını ifade etmektedir.

Hata terimleri arasında ikinci dereceden otokorelasyon olup olmadığını belirleyen AR2 testi sonuçlarına bakıldığında, tek aşamalı Fark GMM tahmincisi hariç diğer tüm modellerin olasılık değerlerinin $\mathrm{p}>0,05$ olduğu gözlemlenmiştir. $\mathrm{Bu}$ sonuç, kurulan modellerde hata terimleri arasında ikinci dereceden otokorelasyon olmadığını, ayrıca tek aşamalı Fark GMM tahmincisi hariç diğer tüm modellerde GMM tahmincilerinin tutarlı olduğunu ifade etmektedir.

Arellano ve Bond'un otokorelasyon testine ait hipotezler ise aşağıdaki gibidir.

$\mathrm{H}_{0}$ : Hata terimleri arasında ikinci mertebeden otokorelasyon yoktur.

$\mathrm{H}_{1}$ : Hata terimleri arasında ikinci mertebeden otokorelasyon vardır. 
$\mathrm{Bu}$ durumda tek aşamalı Fark GMM tahmincisi hariç diğer tüm modellerin olasılık değerleri $\mathrm{p}>0,05$ olduğundan " $\mathrm{H}_{0}$ : Hata terimleri arasında ikinci mertebeden otokorelasyon yoktur." hipotezi kabul edilmiştir. Başka bir ifade ile elde edilen sonuç değişkenler arasında bir otokorelasyon problemi bulunmadığı göstermektedir.

Elde edilen tüm varsayım testlerinin (Wald, Sargan-Hansen, AR1 ve AR2) sonuçlar1 değerlendirildiğinde yalnızca iki aşamalı Fark GMM ve Sistem GMM tahmincilerine ilişkin modellerin anlamlı olduğu gözlemlenmektedir. Dolayısıyla bağımlı ve bağımsız değişkenler arasında panel veri analizi sonuçlarının değerlendirilmesinde tek aşamalı Fark GMM ve Sistem GMM tahmincilerine ilişkin modeller kapsam dışında bırakılmıştır.

Bu anlamda tablo 9'da elde edilen sonuçlardan hareketle öncelikle dinamik panel veri analizi sonuçlarına ilişkin iki aşamalı fark GMM sonuçları, daha sonra ise iki aşamalı sistem GMM sonuçları yorumlanacaktır.

$\mathrm{IHT}_{\mathrm{t}-1}$ değişkeni için iki aşamalı fark GMM model tahmin sonucu incelendiğinde, model katsayısının -0.555643 , olasılık değerinin ise $(0,0000)$ olduğu gözlemlenmektedir. Olasılık değerinin $\mathrm{p}<0,05$ olması kurulan modelin anlamlı olduğunu göstermektedir. Model katsayısı; analize dahil edilen işletmeler üzerinde negatif tahakkuklar yöntemi kullanılarak hesaplanan bir önceki dönem ihtiyatlılık düzeyi ile cari dönemdeki ihtiyatlılık düzeyi arasında negatif ve anlamlı bir ilişki olduğunu göstermektedir.

İki aşamalı fark GMM modelinin bağımsız değişkeni olan $\mathrm{K} / \mathrm{Z}$ değişkeni katsayı değerinin 1.105023, olasılık değerinin ise (0.0000) olduğu gözlemlenmektedir. Bu değerler kurulan modelin ve elde edilen sonuçların \%1 anlamlılık düzeyinde anlamlı olduğunu göstermektedir. İhtiyatlılık düzeyi ile dönem kar zararı arasında pozitif bir ilişki bulunmaktadir.

İki aşamalı fark GMM modelinin bağımsız değişkeni olan $\mathrm{KK} / \mathrm{Z}$ değişkeni katsayı değerinin $\quad-0.423619$, olasılık değerinin ise $(0,0000)$ olduğu gözlemlenmektedir. Bu değerler kurulan modelin ve elde edilen sonuçların \%1 anlamlılık düzeyinde anlamlı olduğunu göstermektedir. Ayrıca ihtiyatlılık düzeyi ile toplam kapsamlı kar zararı arasında negatif bir ilişki bulunduğunu göstermektedir.

Ulusal ve uluslararası muhasebe literatüründe karlılık oranları ile ihtiyatlılık düzeyi arasındaki ilişkiyi ele alan çalışmalar bulunmaktadır. $\mathrm{Bu}$ çalışmaların sonuçlarına bakıldığında, birbirlerini desteklemedikleri, yani karlılık oranları ile ihtiyatlılık düzeyi arasında bir ilişki olduğuna dair bir fikir birliğgi sağlanamadığı tespit edilmiştir. Örneğin; Zeytinoğlu ve Polat (2018) ve Yuliarti ve Yanto (2017) çalışmalarında karlılık oranları ile ihtiyatlılık arasında negatif ve anlamlı bir ilişki olduğu sonucuna ulaşırken, Elshandidy ve Ahmed (2014) ise karlılık oranları ile ihtiyatlılık arasında pozitif ve anlamlı bir ilişki olduğu sonucuna ulaşmıştır. Ayrıca Aminu ve Hassan (2017) ise koşullu ihtiyatlılık ile karlılık oranı arasında pozitif, koşulsuz ihtiyatlılık ile karlılık oranı arasında negatif bir ilişki olduğu sonucuna ulaşmıştır. Yukarıda değinilen söz konusu çalışmaların araştırma kapsamı incelendiğinde maksimum 7 yıl ile sınırlandığı gözlemlenmiştir. Başka bir ifadeyle karlılık ve ihtiyatlılık düzeylerinin tespitinde kısa dönemli veriler kullanılmıştır. Kısa vadede ihtiyatlılık arttıkça karlılık azalacağından dolayı, ihtiyatlılık ölçümünde kısa dönemli verilerin kullanılması sağlıklı sonuçların ulaşılamamasına neden olacaktır. Ancak uzun vadede yavaş 
artan ihtiyatlılık düzeyi, istikrarlı bir kar artışı sağlamaktadır. Dolayısıyla 15 yıllık uzun dönemli verilerin kullanıldığı bu çalışmamızdan elde edilen sonuçlar, kısa dönemli benzer çalışmaların sonuçları ile karşılaştırıldığında daha doğru ve anlamlı sonuçlar sunacaktır.

İki aşamalı fark GMM modelinin son bağımsız değişkeni olan HF değişkeni katsayı değerinin -53853.76 , olasılık değerinin ise 0,0067 olduğu gözlemlenmektedir. $\mathrm{Bu}$ değerler kurulan modelin ve elde edilen sonuçların \%1 anlamlılık düzeyinde anlamlı olduğunu, ayrıca ihtiyatlılık düzeyi ile dönem sonu hisse senedi fiyatı arasında negatif bir ilişki bulunduğunu göstermektedir. Başka bir ifade ile bu durum negatif tahakkukların negatif yönde, dönem sonu hisse senedi fiyatının pozitif yönde hareket ettiğini ifade etmektedir. İhtiyatlılık düzeyi ile dönem sonu hisse senedi fiyatı arasında negatif bir ilişkinin bulunması beklentimiz ile uyuşmaktadır.

Uluslararası muhasebe literatüründe karlılık oranları ile ihtiyatlılık düzeyi arasındaki ilişkinin sonuçlarında olduğu gibi, dönem sonu hisse senedi fiyatı ile ihtiyatlılık düzeyi arasındaki ilişkinin sonuçlarının da birbirlerini desteklemedikleri, çalışmaların sonuçları arasında bir fikir birliği olmadığı görülmektedir. Örneğin; Ademola vd. (2017) ile Francis vd. (2013) çalışmalarında ihtiyatlılık ile hisse senedi fiyatı arasında pozitif ve anlamlı bir ilişki olduğu sonucuna ulaşırlarken, lshandidy ve Hassanein (2014) ise çalışmasında ihtiyatlılık ile hisse senedi fiyatı arasında negatif ve anlamlı bir ilişki olduğu sonucuna ulaşmıştır. $\mathrm{Bu}$ açıdan çalışmamızda ihtiyatlılık düzeyi hesaplanırken negatif tahakkuklar yönteminin kullanılması yani negatif tahakkuklar tutarının negatif olarak artması işletmelerin ihtiyatlı davrandığı anlamına geldiğinden, çalışmamız Ademola vd. (2017) ile Francis vd. (2013)'in çalışmalarını desteklemektedir.

İki aşamalı sistem GMM modeli tahmin sonuçları incelendiğinde, $\mathrm{IHT}_{\mathrm{t}-1}$ değişkeni için model katsayısının -0.7421592 , olasılık değerinin ise $(0,0000)$ olduğu gözlemlenmektedir. Olasılık değerinin $p<0,05$ olması kurulan modelin anlamlı olduğunu göstermektedir. Model katsayısı; analize dahil edilen işletmeler üzerinde negatif tahakkuklar yöntemi kullanılarak hesaplanan bir önceki dönem ihtiyatlılık düzeyi ile cari dönemdeki ihtiyatlılık düzeyi arasında negatif bir ilişki olduğunu göstermektedir.

İki aşamalı sistem GMM modelinin bağımsız değişkeni olan $\mathrm{K} / \mathrm{Z}$ değişkeni katsayı değerinin 1.177275, olasılık değerinin ise (0.0000) olduğu gözlemlenmektedir. Bu değerler kurulan modelin ve elde edilen sonuçların \%1 anlamlılık düzeyinde anlamlı olduğunu göstermektedir. İhtiyatlılık düzeyi ile dönem kar zararı arasında pozitif bir ilişki bulunmaktadir.

İki aşamalı Sistem GMM modelinin bağımsız değişkeni olan $\mathrm{KK} / \mathrm{Z}$ değişkeni katsayı değerinin -0.3361028 , olasılık değerinin ise $(0,0000)$ olduğu gözlemlenmektedir. Bu değerler kurulan modelin ve elde edilen sonuçların $\% 1$ anlamlılık düzeyinde anlamlı olduğunu göstermektedir. Ayrıca ihtiyatlılık düzeyi ile toplam kapsamlı kar zararı arasında negatif bir ilişki bulunduğunu göstermektedir.

İki aşamalı sistem GMM modelindeki bağımsız değişkenler olan $\mathrm{K} / \mathrm{Z}$ ve $\mathrm{KK} / \mathrm{Z}$ değişkenleri ile, bağımlı değişken olan IHT değişkeni arasındaki ilişki literatür bağlamında incelendiğinde; iki aşamalı fark GMM sonuçları ile benzer yorumlar geçerlidir. İhtiyatlılık düzeyi ile toplam kapsamlı kar ve dönem kar zararı arasındaki ilişkiyi ayrı ayrı ele alan bir 
çalışmaya rastlanılmamıştır. Fakat ulusal ve uluslararası muhasebe literatüründe karlılık oranları ile ihtiyatlılık düzeyi arasındaki ilişkiyi ele alan çalışmalar bulunmaktadır. $\mathrm{Bu}$ çalışmaların sonuçlarına bakıldığında, birbirlerini desteklemedikleri, yani karlılık oranları ile ihtiyatlılık düzeyi arasında bir ilişki olduğuna dair bir fikir birliği sağlanamadığı tespit edilmiştir. Örneğin; Zeytinoğlu ve Polat (2018) ve Yuliarti ve Yanto (2017) çalışmalarında karlılık oranları ile ihtiyatlılık arasında negatif ve anlamlı bir ilişki olduğu sonucuna ulaşırken, Elshandidy ve Ahmed (2014) ise karlılık oranları ile ihtiyatlılık arasında pozitif ve anlamlı bir ilişki olduğu sonucuna ulaşmıştır. Ayrıca Aminu ve Hassan (2017) ise koşullu ihtiyatlılık ile karlılık oranı arasında pozitif, koşulsuz ihtiyatlılık ile karlılık oranı arasında negatif bir ilişki olduğu sonucuna ulaşmıştır.

İki aşamalı sistem GMM modelinin son bağımsız değişkeni olan HF değişkeni katsayı değerinin -47183.32 , olasıl1k değerinin ise $(0,0460)$ olduğu gözlemlenmektedir. Bu değerler kurulan modelin ve elde edilen sonuçların \%5 anlamlılık düzeyinde anlamlı olduğunu, ayrıca ihtiyatlılık düzeyi ile dönem sonu hisse senedi fiyatı arasında negatif bir ilişki bulunduğunu göstermektedir.

Uluslararası muhasebe literatüründe karlılık oranları ile ihtiyatlılık düzeyi arasındaki ilişkinin sonuçlarında olduğu gibi, dönem sonu hisse senedi fiyatı ile ihtiyatlılık düzeyi arasındaki ilişkinin sonuçlarının da birbirlerini desteklemedikleri, çalışmaların sonuçları arasında bir fikir birliği olmadığı görülmektedir. Örneğin Francis vd. (2013), Ademola vd. (2017) ile Zhong ve Li (2017) çalışmalarında ihtiyatlılık ile hisse senedi fiyatı arasında pozitif ve anlamlı bir ilişki olduğu sonucuna ulaşırlarken, lshandidy ve Hassanein (2014) ise çalışmasında ihtiyatlılık ile hisse senedi fiyatı arasında negatif ve anlamlı bir ilişki olduğu sonucuna ulaşmıştır. Bu açıdan çalışmamızda ihtiyatlılık düzeyi hesaplanırken negatif tahakkuklar yönteminin kullanılması yani negatif tahakkuklar tutarının negatif olarak artması işletmelerin ihtiyatlı davrandığı anlamına geldiğinden, çalışmamız Francis vd. (2013), Ademola vd. (2017) ve Zhong ve Li (2017)'nin çalışmalarının sonuçlarıyla örtüşmektedir.

İki aşamalı Fark GMM ve Sistem GMM sonuçları bağımlı ve bağımsız değişkenler açısından birlikte yorumlandığında her iki tahminciden elde edilen sonuçların birbirini desteklediği görülmektedir. Aşağıdaki tabloda araştırmanın hipotezleri, beklenen etki ve tahmincilere ilişkin sonuçlar verilmiştir.

Tablo 7. Araştırmanın Hipotezleri, Beklenen Etki ve Tahmincilere İlişkin Sonuçlar

\begin{tabular}{|l|c|c|}
\hline Hipotezler & Beklenen Etki & Sonuç \\
\hline $\begin{array}{l}\mathbf{H}_{1}: \text { TMS/TFRS'leri uygulayan işletmelerin ihtiyatlılık } \\
\text { düzeylerinin artması, uzun vadede dönem karında dengeli bir } \\
\text { artı̧ı sağlamaktadır }\end{array}$ & Negatif & Pozitif \\
\hline $\begin{array}{l}\mathbf{H}_{2} \text { TMS/TFRS'leri uygulayan işletmelerin ihtiyatlılık } \\
\text { düzeylerinin artması, uzun vadede kapsamlı karda dengeli bir } \\
\text { artışı sağlamaktadır }\end{array}$ & Negatif & Negatif \\
\hline $\begin{array}{l}\mathbf{H}_{3}: \text { TMS/TFRS'leri uygulayan işletmelerin ihtiyatlılık } \\
\text { düzeylerinin artması, dönem sonu hisse senedi fiyatlarını da } \\
\text { artırmaktadır. }\end{array}$ & Negatif & Negatif \\
\hline
\end{tabular}

Not: Tabloda belirtilen sonuçlar İki aşamalı Fark GMM ve Sistem GMM sonuçlarını göstermektedir. 
Tablo 7'de görüldüğü üzere $\mathrm{H}_{1}$ hipotezinden elde edilen sonucun beklentimizle uyuşmadığ $1, \mathrm{H}_{2}$ ve $\mathrm{H}_{3}$ hipotezlerinden elde edilen sonuçların ise beklentimiz ile uyuştuğu gözlemlenmektedir.

\section{SONUÇ}

Son dönemlerde ihtiyatlılık ilkesi üzerine yapılan çalışmalar göz önüne alındığında, ihtiyatlılık ilkesinin hem ülke hem de işletmeler açısından finansal raporlama üzerinde önemli bir etkiye sahip olduğu görülmektedir. Bu açıdan geniş bir kitleyi etkileyen ihtiyatlılık ilkesi, muhasebe literatüründe ele alınması gereken önemli bir konu olarak değerlendirilebilir.

Yapılan bu çalışmada Borsa İstanbul'da 2005-2019 yılları arasında kesintisiz olarak işlem gören farklı sektörlerde faaliyet gösteren 15 işletmeye ait 15 yıllık veriler yıllık bazda incelenmiş ve toplam 960 veri üzerinde dinamik panel veri analizi yöntemi uygulanarak, işletmelerin ihtiyatlılık düzeyleri ile finansal sürdürülebilirlikleri arasında bir ilişki olup olmadığı test edilmiştir. Dinamik panel veri analizi sonuçlarına göre araştırmaya dahil edilen işletmelere ait Tek aşamalı Fark GMM ve Sistem GMM tahmincilerine ilişkin Sargan-Hansen testi sonuçlarına göre modellerin olasılık değerinin $\mathrm{p}<0,05$ olduğu tespit edilmiştir. $\mathrm{Bu}$ değer kullanılan araç değişkenlerin içsel olduğunu ifade ettiğinden, Sargan-Hansen testine ait " $\mathrm{H}_{0}$ : Araç değişkenler dişsaldır. (moment koşulları geçerlidir)" hipotezi reddedilerek Fark GMM ve Sistem GMM tahmincileri tek aşamalı modellerinin bir bütün olarak anlamsız olduğu sonucuna ulaşılmıştır. Dolayısıyla söz konusu modeller kapsam dışında bırakılarak, en güvenilir tahminciler olasılık değerlerinin p >0,05 olduğu İki Aşamalı Fark GMM ve Sistem GMM Tahmincileri olduğu belirlenmiştir.

Sonuç olarak İki Aşamalı Fark GMM ve Sistem GMM Tahmincilerinden hareketle; Negatif Tahakkuklar Yöntemine göre, TMS/TFRS'leri uygulayan işletmelerin ihtiyatlılık düzeyleri arttıkça, dönem kar zararı azalmaktadır. İkinci olarak TMS/TFRS'leri uygulayan işletmelerin ihtiyatlılık düzeyleri arttıkça, toplam kapsamlı karı artmaktadır. Son olarak ise TMS/TFRS'leri uygulayan işletmelerin ihtiyatlılık düzeyleri arttıkça, dönem sonu hisse senedi fiyatları da buna paralel olarak arttığı tespit edilmiştir.

\section{KAYNAKLAR}

Ademola, Osundina J- Moses,Olayinka (2017) , “Accounting Conservatism and Its Benefits to Shareholders in Developing Capital Market: Evidence from Nigeria”, Journal of Accounting and Finance Vol. 17(1), pp.89-96

Aktürk, Ahmet-Durmuş, Acar (2012) , "Muhasebede İhtiyatl11ık Kavramı Ve Temelleri”, Mali Çözüm Dergisi”, Eylül-Ekim, ss.17-38.

Aminu, Lawal- Hassan, Shehu Usman (2017), “Accounting Conservatism And Financial Performance Of Nigerian Deposit Money Banks”, Scholedge International Journal of Busines Policy \& Governance, Vol:4, Issue:12, pp. 124-135

Anwer, Ahmed- Morton, R - Schaefer,T. (2000), Accounting Conservatism and the Valuation of Accounting Numbers: Evidence on the Feltham-Ohlson (1996) Model”, Journal of Accounting, Auditing \& Finance, C. 15, S. 3, pp. 271-92 
Anwer, S.Ahmed-Bruce, K.-Billings-Richard, M. Morton-Mary,Stanford (2002), "The Role of Accounting Conservatism in Mitigating Bondholder-Shareholder Conflicts over Dividend Policy and in Reducing Debt Costs”, The Accounting Review, C. 77, S. 4, pp. 867-90

Anwer, S.-Scott, Duellman (2007), “Accounting Conservatism And Board Of Director Characteristics: An Empirical Analysis”, Journal of Accounting and Economics, C. 43, S. 2, pp. 411-37.

Ball, Ray- Robin, Ashok- Sadka, Gil (2008), "Is Financial Reporting Shaped by Equity Markets or by Debt Markets? An International Study of Timeliness and Conservatism”, Review of Accounting Studies, C. 13, S. 2, pp. 168-205

Ball, Ray-Robin, Ashok- Wu, Shuang Joanna (2003), “Incentives Versus Standards: Properties Of Accounting İncome İn Four East Asian Countries", Journal of Accounting and Economics, Vol. 36, No. 1, pp. 235-70,

Barker, Richard (2019), "Conservatism, Prudence And The IASB’s Conceptual Framework”, Accounting And Business Research, Vol. 45, No. 4, pp.514-538.

Bauman, Mark P (1999), “An Empirical Investigation of Conservatism in Book Value Measurement”, Managerial Finance, Vol.25, No.12, pp.42-57

Beatty, Anne- Weber, Joseph-Yu, Jeff Jiewei (2008), “Conservatism and Debt”, Journal of Accounting and Economics, Vol. 45, No. 2, pp. 154-74,

Beaver, William - Ryan, Stephen (2000), "Biases and Lags in Book Value and Their Effects on the Ability of the Book-to-Market Ratio to Predict Book Return on Equity”, Journal of Accounting Research, Vol. 38, No. 1, pp. 127-148.

Beekes, Wendy- Pope, Peter-Steven, Young (2004), “The Link Between Earnings Timeliness, Earnings Conservatism and Board Composition: Evidence from the UK”, Corporate Governance: An International Review, Vol. 12, No. 1, pp. 47-59

Çınar, Serkan (2010), "OECD Ülkelerinde Kişi Başına GSYİH Durağan Mi?: Panel Veri Analizi", Marmara Üniversitesi İktisadi ve İdari Bilimler Dergisi, Cilt 29, Say1 2, ss.591-601

Elshandidy, Tamer- Hassanein, Ahmed (2014), "Do IFRS and Board of Directors' Independence Affect Accounting Conservatism?”, Applied Financial Economics, C. 24, S. 16, pp. 1091-1102

Ertuğrul, Ayşe Nilgün (2014), “Geleneksel Muhasebeden Uluslararası Finansal Raporlamaya Geçişte İhtiyatlılık Kavramı”, Niğde Üniversitesi IİBF Dergisi, Cilt: 7, Sayı: 1, ss.215-227.

Francis, Bill- Hasan, Iftekhar- Wu, Qiang (2013) "The Benefits of Conservative Accounting to Shareholders”, Accounting Horizons American Accounting Association, Vol. 27, No. 2, pp. 319-346 
Gao, Pingyang (2013), "A Measurement Approach to Conservatism and Earnings Management”, Journal of Accounting and Economics, C. 55, S. 2-3, pp. 251-268

Givoly, Dan- Hayn, Carla (2000), “The Changing Time-Series Properties of Earnings, Cash Flows and Accruals: Has Financial Reporting Become More Conservative?” Journal of Accounting and Economics No:29 s.287.

Göçer, İsmet- Mercan, Mehmet - Hotunluoğlu, Hakan (2012), "Seçilmiş OECD Ülkelerinde Cari İşlemler Açığının Sürdürülebilirliğgi: Yatay Kesit Bağımlılı̆̆ı Altında Çoklu Yapısal Kırılmalı Panel Veri” Maliye Dergisi, Sayı 163, ss. 449-467,

Gülhan, Ozan- Karaarslan, Serhan (2019), “Türkiye’de Kurumsal Yönetim Uyum Derecelendirmesi ve İhtiyatlı Muhasebe İlişkisi”, Muhasebe ve Vergi Uygulamaları Dergisi, C. 13, S. 1, ss.99-113

İltaş, Yüksel (2017), "Nakde Dönüşüm Süresinin Panel Birim Kök Testleri İle İncelenmesi Türkiye Örneği", Uluslararası Katılımlı 21. Finans Sempozyumu, ss.563-577

LI, Jing, (2013), "Accounting Conservatism and Debt Contracts: Efficient Liquidation and Covenant Renegotiation", Contemporary Accounting Research, Vol. 30 No. 3, pp. 1082-1098.

Topaloğlu, Emre Esat(2018), "Bankalarda Finansal Kırılganlığı Etkileyen Faktörlerin Panel Veri Analizi ile Belirlenmesi”, Eskişehir Osmangazi Üniversitesi İktisadi ve İdari Bilimler Dergisi, C. 13, S. 1, ss.15-38

Vardar, Gizem Çopur (2018), "Uluslararası Muhasebe/Finansal Raporlama Standartlarının Koşullu Ve Koşulsuz İhtiyatlılık Uygulamaları Açısından Değerlendirilmesi: Finansal Tabloların İhtiyatlılığı Üzerindeki Etkisine İlişkin Bir Literatür Araştırması", Muhasebe Bilim Dünyası Dergisi, C. 20, ss. 150-72

Watts, Ross L., ( 2003) "Conservatism in Accounting Part II: Evidence and Research Opportunities”, Accounting Horizons, C. 17, S. 4, pp. 287-301

Yıldırım, Kemal- Kostakoğlu S. Fatih (2015), "Ülkelerin Ekonomik Performansı Üzerinde Regülasyonun Etkileri” Anadolu Üniversitesi Sosyal Bilimler Dergisi, Cilt: 15, Sayı: 2, Eskişehir, ss.45-56.

Yuliarti, Dita- Yanto, Heri (2017), "The Effect of Leverage, Firm Size, Managerial Ownership, Size of Board Commissioners and Profitability to Accounting Conservatism” Accounting Analysis Journal 6(2), pp. 173-184

Zeytinoğlu, Emin (2018), "Muhasebede İhtiyatlılı̆̆1 Etkileyen Faktörler: Borsa İstanbul Örneği”, International Journal Of Social Humanities Sciences Research (JSHSR), C. 5, S. 20, ss. 753-762 
